\title{
CARTILLAS POLÍTICAS Y CATECISMOS CONSTITUCIONALES EN EL CÁDIZ DE LAS CORTES: UN GÉNERO VIEJO PARA LA CREACIÓN DE UNA NUEVA SOCIEDAD ${ }^{1}$
}

\author{
BEATRIZ SÁNCHEZ HITA \\ Universidad de Cádiz
}

Corría 1792 cuando Cabarrús se expresaba en los siguientes términos:

\begin{abstract}
Haya, pues, en cada lugar una o más escuelas, según su población, destinada a enseñar a los niños a leer, escribir, contar, los primeros elementos de geometría práctica y un catecismo político en que se comprendan los elementos de la sociedad en que viven y los beneficios que reciben de ella. [...]

$\mathrm{Y}$ si se instruyese una generación entera, ¿no llegaría una época en que los que gobiernan serían justos y consecuentes porque serían ilustrados? (Cabarrús 1990: 79-80).
\end{abstract}

Estas palabras conectan con toda una serie de proyectos que para la mejora de la educación trataron de poner en práctica las figuras más señeras de la Ilustración española —Olavide, Jovellanos, Campomanes, etc.-., cuyo quehacer se vio drásticamente frenado como consecuencia del «pánico de Floridablanca» hacia la Francia revolucionaria y el consiguiente establecimiento de un cordón sanitario que impedirá la difusión de todo aquello que huela a francés. Habría que esperar al levantamiento popular del dos de mayo de 1808, para salir del silencio e iniciar (o continuar) las anheladas reformas, recuperándose todo este caudal de pensamiento que sustentará los cambios que en el sistema educativo se van a producir. Dichos cambios, en última instancia, anuncian el ocaso del Antiguo Régimen y llevan aparejada una profunda reestructuración de la sociedad. Y es que, como señala Artola, se parte ahora de un principio nuevo: «el ciudadano, piedra fundacional de la sociedad clasista y el Estado liberal» (1975: 527),

\footnotetext{
${ }^{1}$ Este estudio se suscribe al proyecto BFF2002-01366 de la Dirección General de Investigación del Ministerio de Ciencia y Tecnología: La prensa española en la época de las Cortes de Cádiz.
}

Rlit, LXV, 130 (2003), 541-574 
de modo que la asimilación por parte de éste de su nueva situación será la vía más efectiva para garantizar la revolución emprendida.

Entronca este parecer con la «tarea pedagógico-moral» (Aranguren 1974: 18) que caracteriza a la Ilustración española y que, bajo la utópica idea de que bastaba con conocer la verdad para respetarla y defenderla, será retomada por este primer liberalismo. En este orden de cosas, resultan sintomáticas las palabras de la Marquesa de Astorga, anónima traductora en el Cádiz de 1812 de la obra Los Derechos, y Deberes del Ciudadano de Mably ${ }^{2}$, en la introducción de la misma:

El único fondo con que el hombre reflexivo debe contar para prometerse que los Pueblos conseguirán el fruto de sus revoluciones, es en razón de la ilustración de la masa en general de Ciudadanos en el conocimiento de la Moral Política (Ponce de León 1812: XI-XII).

Este sentir explica la rapidez con que son abordadas - que no puestas en práctica- por la Junta Central las reformas en el plano educativo: por decreto de 2 de junio de 1809 se establece una de las siete juntas para el arreglo de la instrucción pública, y en noviembre del mismo año Jovellanos redacta las Bases para la formación de un plan de instrucción pública. Sin embargo, hasta 1814 no existirá un texto legal que sustente la reforma: el Dictamen y proyecto de decreto sobre el arreglo de la Enseñanza Pública (7 de marzo de 1814), inspirado en el Informe Quintana ${ }^{3}$. Estos programas evidencian los rasgos básicos del liberalismo español y en ellos conviven «la herencia de la Ilustración y el legado doctrinal de la gran revolución de 1789» (Puelles 1980: 55). En efecto, las teorías desarrolladas por Jovellanos y Quintana, en este período denotan una clara influencia de Taylleraud y sus Rapport sur l'instruction publique (1791) y Projet de décret sur l'instruction publique (1791) y Condorcet con Rapport et projet de décret sur l'organization generale de l'instruction publique (1793) ${ }^{4}$.

En este proceso la prensa va a desempeñar un doble papel, ya que de un lado se hará eco de las discusiones que en la tribuna de las Cortes se están produciendo, y de otro será el mecanismo más eficaz en la difusión de las nuevas teorías; advierte M. ${ }^{a}$ Cruz Seoane, al respecto, que «los periódicos fueron el principal vehículo de instrucción para los lectores espa-

\footnotetext{
${ }^{2}$ En La Abeja Española, n. ${ }^{\circ} 10$ (21/IX/1812) bajo el epígrafe de «Injusta prevención contra ciertas clases y estados» se elogia a la Marquesa de Astorga por esta labor. Palau (T. VIII, entrada 145551) la cita también como traductora de la obra de Mably. Adolfo de Castro atendiendo a los eventos más destacados de 1812 en suelo gaditano dirá que «la Excma. Sra. Marquesa de Astorga, Condesa de Altamira, oculta su nombre en esta versión y en este prólogo en que discurre en pro de las libertades públicas, más en sentido aproximado a la democracia que a la grandeza de su nacimiento» (1864: 124).

${ }^{3}$ Dérozier (1978: 700-707) da cuenta de la formación de las comisiones de trabajo que fueron designadas y la labor de éstas hasta la vuelta de Fernando VII.

${ }^{4}$ Puede consultarse Ángela del Valle López (1990).
} 
ñoles en el tiempo que duró la guerra. [...] El círculo de personas instruidas en ciencias políticas y morales, hasta entonces exiguo, se amplió enormemente gracias a los periódicos» (1977: 26). De manera que los periódicos adquieren una importancia capital en la formación del ciudadano, fundamentalmente en lo que a su faceta social se refiere, pues urge que conozca los aspectos básicos de ese engranaje del que es pieza central y el medio no podía resultar más propicio. Esto explica la proliferación de artículos y opúsculos en los que subyace una verdadera intención pedagógica.

Entre los últimos habría que destacar los catecismos y cartillas políticas, civiles, constitucionales, etc., que adquirirán una importancia notable, ya que de acuerdo con los objetivos del Estado persiguen «la incorporación o adhesión del súbdito/ciudadano a su proyecto político» (Muñoz 1987: 195), bajo esa óptica esbozada por Hazard en la que la educación se hace cívica y «debe llegar a ser una parte integrante de la política, con doble título: la forma y es formada por ella» (1946: 178). Para alcanzar este fin, y a tenor del importante analfabetismo, resulta extraordinariamente útil el modelo catequístico, cuyos orígenes se remontan a la disputatio medieval, y que contaba con un amplio cultivo en el ámbito religioso, viviendo su momento de auge en la Contrarreforma, extendiéndose su uso hasta fechas recientes - baste pensar en las múltiples ediciones que de los célebres Astete y Ripalda se llevarán a cabo acomodando su maniquea doctrina a las exigencias del momento-. Se aprecia, por lo tanto, cómo la vertiente religiosa originaria del catecismo comienza a convivir durante el período de la Guerra de la Independencia con otra de cariz social, que hace que, sin que desaparezca en su versión tradicional y tradicionalista ${ }^{5}$, se emplee ahora su molde formal con fines de adoctrinamiento político. En suma, y como acertadamente apunta Aymes (1988: 23), la necesidad de una educación patriótica dota al catecismo religioso de una finalidad cívica.

No en vano, en virtud de su sencilla estructura ${ }^{6}$ de preguntas y respuestas con sentido unívoco, se propicia que los contenidos políticos sean memorizados - que no necesariamente aprehendidos- sin dificultad; al tiempo que la política adquiere esa imagen sacrosanta que acabará convirtiendo a la Constitución en «Sagrado Código».

${ }^{5}$ Una idea de la importante difusión que tuvo el catecismo religioso antes del conflicto bélico y en el conjunto del siglo XIX puede extraerse de las cifras que manejan Meléndez y Saugnieux (1984-1985), quienes constatan un número de 355 catecismos, catones y demás obras de ortodoxas, y de los títulos y reediciones reseñados por Morales, quien en la introducción a su estudio señala que «El conjunto más numeroso corresponde a la enseñanza religiosa, con dedicación casi exclusiva a la doctrina cristiana, pudiendo mencionar las innumerables ediciones y adaptaciones de los clásicos en la materia, como los catecismos de los PP. Astete, Ripalda y Fleuri» (1990: 13-14 y 21-78).

${ }^{6}$ Sobre la estructura y la definición del género puede consultarse Nydia M. Ruiz (1995). 
Ahora bien, hay que hacer una leve matización, ya que a la vez que el catecismo se concibe como un eficaz medio de formación del ciudadano, también se va a entender como un arma más de la cruzada antinapoleónica, situándose al lado de pasquines, hojas volanderas, proclamas, manifiestos, sermones y demás escritos que tratan de exaltar el patriotismo. De modo que a la hora de enfrentarse al estudio de estas producciones debe atenderse a esta doble faceta, a la que habrá que añadir determinadas consideraciones de carácter cronológico o geográfico, pues, en la mayoría de los casos, se puede observar una relación directa con las circunstancias sociales bajo las que surgen auspiciadas; lo que ocasiona que una vez pasada su coyuntura queden obsoletas (no obstante, es preciso hacer una salvedad en lo que se refiere a aquellos destinados a explicar la Constitución, que se incorporan a la enseñanza, y que permanecerán vigentes mientras ésta lo esté, y que en casos aislados volverán a reimprimirse con modificaciones en el Trienio y la Regencia).

El caso de Cádiz resulta paradigmático al respecto debido a su peculiar situación durante la Guerra de la Independencia. En 1810 será esta ciudad uno de los pocos territorios que permanezca libre de la invasión napoleónica, lo que tendrá como resultado un extraordinario aumento de la población, las Cortes se instalan en la capital desde febrero de 1811, y en ellas el 19 de marzo de 1812 se promulgará la Constitución (texto que con sus 384 artículos se convierte en epítome del paso del Antiguo Régimen a una sociedad de clases basada en el principio de soberanía nacional); esto se refleja en la importancia de su prensa periódica de marcado carácter liberal, a la que se suma la ingente cantidad de folletos, pasquines y demás que sustentan el clima de discusión política y por ende, cultural y social. En este medio se encuadran los catecismos, cartillas y otras formas político-literarias, que desde la insurrección de mayo, tras la que se instaura una libertad de imprenta de facto, proliferan en el país.

En Cádiz, frente al resto de España donde la impresión de catecismos religiosos supera a los políticos, serán estos últimos los que cobren primacía alcanzando un número de seis durante el período de la Guerra de la Independencia, según Morales (1990: 12) ${ }^{7}$; a los que estimo necesario agre-

\footnotetext{
${ }^{7}$ Señala que «de los 80 catecismos [políticos] catalogados, el $26 \%$ aparecen entre 1808 y 1814, seis de ellos en Cádiz» (1990: 12). En esta obra (Apéndice III, 87-94, entradas $8,35,36,49,51$ y 70 ) en lo que se refiere a Cádiz se señalan los siguientes títulos en los que se centrará parte del presente estudio (incluyo entre paréntesis la localización de las fuentes en que me baso):

Catecismo patriótico. Cádiz, en la Oficina de Don Nicolás Gómez de Requena, 1809, $4^{\circ}, 8$ pp. (BN. Colección Gómez Imaz. R. 60868).

Catecismo político para instrucción del pueblo español. Cádiz, Imprenta Real, 1810, pequeño $8^{\circ}$, 3h.-24 pp. (Capitán 1978: 113-131).

Moya Luzuriaga (Andrés de). Catecismo de doctrina civil. Cádiz, Imprenta de la Junta Superior de Gobierno, 1810, 16², 32 pp. (Ruiz de Azúa 1989: 49-63).
} 
gar esas obras que sin contener en su título la denominación de catecismo, adoptan la estructura y finalidad de éstos ${ }^{8}$. De otro lado, cabe destacar la práctica ausencia de catecismos de contenido servil, lo cual explica que las citadas obras sufran censuras y descalificaciones desde las páginas de los representantes del sector conservador. Claro ejemplo de esto son las críticas que en las páginas del Diccionario razonado manual se hace del Catecismo de doctrina civil de Andrés de Moya Luzuriaga:

[...] Un célebre médico de nuestros días y una de las antorchas que nos han de guiar según lo dice modestamente en un papel (que ya murió) en que tenía una mitad o una tercera parte, ha estado para mataros de un accidente apoplético dándoos un catecismo de doctrina no cristiana, civil que los diablos que lo puedan digerir; pero todos estos y otros males los evitaré yo con este diccionario (Pérez Vidal 1994: 160).

O las que sufrirá la Cartilla del Robespierre español en Suplemento al número 2 del reaccionario Censor general; donde, tras indicar que desde el Robespierre se ha tratado de destruir el carácter español, se la califica de este modo:

[...] es digno de notar la maldita cartilla del ciudadano español, que ha empezado a correr de nuevo en el número 11 publicado con los subsiguientes contra todas las leyes, reglas y orden de los juicios.

Catecismo político arreglado a la Constitución de la monarquía española, para ilustración del pueblo, instrucción de la juventud y uso de las escuelas de primeras letras, por D. J. C. Cádiz, Imprenta de Lerma, 1812. 16², 120 pp. (Ruiz de Azúa 1989: 105-139).

Catecismo político para el uso de la juventud del Alentejo. En La Abeja Española, Imprenta Patriótica, Cádiz, 13 de junio de 1813. (n. ${ }^{\circ} 275$ ).

Breve Catecismo político-español-constitucional que, a imitación del de doctrina cristiana, compuesto por el Sr. Reynoso, presenta al público E. D. D. E. A. En El Duende de los Cafés, Imprenta Hércules, 1814. (Los números en que aparece son el 251 y el 253 , correspondientes al 8 y 10 de abril de 1814).

${ }^{8}$ Así ocurre con las cartillas políticas que aparecen en el ámbito de la prensa periódica. En lo que al caso gaditano se refiere he localizado una «Cartilla Política» obra de J. M. de V. (José Manuel Vadillo) que se incluye en el número 15 (25/IX/1810) de $E l$ Observador, 234-261. Otra obra semejante es «Cartilla del ciudadano español: o breve exposición de sus fueros y obligaciones»; que ve la luz en los números XI-XXI del Robespierre español, publicada por $\mathrm{M}^{\mathrm{a}}$ del Carmen Silva mientras su marido está en la cárcel. Además de las mencionadas existe otra obra cuyo título es el de Cartilla natural y política del ciudadano español, de la que no he podido localizar ningún ejemplar, siendo las únicas noticias de ella la siguiente descripción que se hace en el Diario Mercantil n. ${ }^{\circ} 87$ (5/IV/1813) bajo el subtítulo de «Noticias de Cádiz»: «Aviso. Cartilla natural y política del ciudadano español. / Esta obrita puede servir para conocer los principios de la Constitución, y entre otras cosas que contiene, es apreciable por las reglas que da para hacer las elecciones con acierto y orden conforme al espíritu de la misma Constitución. Se vende en la librería de Carsi, calle Ancha, un tomo en $8^{\circ}$ rústica». Citado también por Riaño (1922: 1813, 140). 
Por dicha cartilla (como se dirá en otra parte) no puede criarse la juventud obediente, y de semejante crianza es imposible que se formen buenos soldados; todo lo cual está tan demostrado que no admite duda ${ }^{9}$.

Por su parte el Padre Alvarado en la undécima de sus célebres Cartas del Filósofo Rancio hace una crítica a la obra de Rousseau que extiende al Robespierre:

[...] Compendio de todas las impiedades, curso completo del ateísmo, cartilla revolucionaria, y cuanto de depravado puede haber, es el pacto social del ateo Juan Jacobo Rousseau: y esta obra incendiaria, que no deja ni altar, ni trono, ni honestidad, ni justicia, ni cosa alguna buena, es el libro maestro de donde han salido las Reflexiones sociales de D. J. C. A. las obras contra el tribunal de la fe, el nuevo Robespierre con muchas cosas del antiguo, [...] (Alvarado 1824: 19).

Y en la primera entrega de la Diarrea de las Imprentas $^{10}$ se califica como tal la mayor parte de la prensa de 1811, incluyéndose también dos de los catecismos de los que en las siguientes páginas trataré:

[...] ¡Qué diluvio de papeles, Dios mío! ¡Qué diarrea! La Tertulia patriótica, el Semanario, el Patriota en las Cortes, el Observador, la Triple Alianza; Anteojo de larga vista, el Microscopio, la Tertulia resucitada, el Duende, el Redactor, al Atisbador, el Despertador, el Cachidiablo, el Cosmopolita, el Catecismo de doctrina civil, el Catecismo político, el Duende hembra, el Zelador del buen orden, el Periódico contra el despotismo militar, el Mentor, el buen Español; ;pero a dónde voy a dar! Me acuerdo ahora de un loco que había en Sevilla, llamado Juan Cerezo, y a todo el que encontraba le decía:

${ }^{9}$ Esta crítica a la obra de Pedro Pascasio Fernández Sardino aparece recogida en un artículo, firmado por $V$. P.: «Aunque es dirigido al diarista de la tarde puede servir de censura al núm. 21 del Robespier (sic)», que cierra toda una serie de censuras iniciadas en el n. ${ }^{\circ} 17$ (271-275) de la primera época del Censor con una carta de $M$. $R$. donde haciendo chanza de la condición de médico del redactor del Robespierre apunta: «Pero vamos a ver su obra que intitula Cartilla. Como estando enfermo dicen que se confesó quizá advertiría no era bueno para el ejercicio de médico, y quiso tomar el cargo de maestro de escuela», que se sigue en los siguientes Censores: n. ${ }^{\circ} 18$ (294-296), n. ${ }^{\circ} 19$ $(3-4)$, n. $^{\circ} 23$ (38-40), n. 24 (41-46), n. 25 (55-56), n. $29(80), n .^{\circ} 32$ (90-92), n. 35 (101-104); y de la segunda época del periódico el citado Suplemento al Censor Núm. 2, que resume en parte las objeciones vertidas sobre la Cartilla. En el n. ${ }^{\circ} 9$ (65-68), en un «Artículo Comunicado» que se continúa en el n. ${ }^{\circ} 19$ (168-169) -donde se advierte en una nota que: «Por no dividir el anterior discurso, damos dos pliegos que servirán para los Censores del 28, de febrero, y 3, de marzo» (estos pliegos no se encuentran en el ejemplar conservado en la BN. R/37489 y 37490 que he consultado) - se lleva a cabo una crítica de la obra en general y de los abusos que de la libertad de imprenta han cometido Sardino y su mujer, M. ${ }^{\mathrm{a}}$ del Carmen Silva.

${ }^{10}$ La Diarrea de las Imprentas. Memoria sobre la epidemia de este nombre, que reina actualmente en Cádiz. Se describe su origen, sus síntomas, su índole perniciosa, su terminación, y su curación. Escribíala en obsequio de la patria afligida el Doctor Pedro Recio de Tirte Afuera. Cádiz: En la oficina de la Viuda de Comes, año de 1811. 16 pp. In $4^{\circ}$. 
«QQué te mato de un papelazo!» ¿Si habrán creído los Escritores que a fuerza de papeles hemos de arrojar a los franceses de España? (8).

Las reprimendas que sufren estas obras por parte del bando conservador no impiden que proliferen. No obstante, parece que, como afirma Clara Álvarez, determinadas circunstancias «limitan considerablemente el ámbito de difusión de estos folletos, especialmente de los liberales, que se dirigían a un público específico, en especial de las zonas urbanas, donde tenían más posibilidades de éxito; un público capaz de entender y sobre todo de incorporar el nuevo prototipo político» (1997: 26). Las peculiaridades de la capital gaditana la convertían, por consiguiente, en escenario proclive a este tipo de expresiones, al tiempo que explican el predominio de los catecismos y cartillas de tendencia liberal, pues será precisamente ésta la mayoritaria entre los refugiados en Cádiz. Tal y como señala Aymes, «de 1810 à 1814 , on observe une prédominance des catéchismes politiques de tendance libérale, car les libéraux, qui dominent aux Cortès et bientôt promulguent une constitution conforme à leur credo, s'employent à défendre leur œuvre» (1988: 29).

Para el estudio de los ocho textos seleccionados, tomaré como referencia la división establecida por Alfonso Capitán Díaz (1990) ${ }^{11}$, quien, para el lapso temporal en cuestión, distingue dos etapas: una preconstitucional (1790-1810) y otra constitucional (1812-1814). En esta agrupación considero oportuno modificar doblemente la primera de las etapas, incluyendo los años obviados (1810-1812): por un lado, hay que reducir el amplio margen temporal, ya que en el caso español, salvando el Catecismo del Estado del jansenista Joaquín Lorenzo Villanueva (1793), hasta la Guerra de la Independencia no se produce una verdadera eclosión de estos escritos (Aymes 1990: 427); por otro, se aprecian ciertas diferencias entre los catecismos aparecidos en los momentos de mayor fragor en la lucha antinapoleónica y los que verán la luz poco antes de la apertura de las sesiones de Cortes (24/IX/1810). En estos últimos el beligerante patriotismo es sustituido por lo que se podrían denominar conatos de reflexión teórica sobre el futuro sistema constitucional.

Considerando estas distinciones se observa cómo, en función de las circunstancias históricas e ideológicas, se producen cambios que afectan incluso a la estructura interna, presentando un diálogo mucho más fluido aquellos catecismos en los que predomina un tono combativo o satírico, y en menor medida en los destinados a la enseñanza de la Constitución (en éstos en ocasiones se establecen largos parlamentos, que ralentizan el intercambio de preguntas y respuestas, destinados a esclarecer ciertos artícu-

${ }^{11}$ La clasificación de Capitán Díaz de 1990 modifica la del mismo autor en 1978, donde distinguía entre un período de iniciación (1790-1810) y otro de perfeccionamiento (1810-1814). 
los), frente a los que poseen un claro objeto de teorización sobre el cambio social que se está produciendo. La suma de estos rasgos da lugar a los tres momentos que en mi opinión pueden distinguirse entre 1808 y 1814: de combate, de especulación teórico-pedagógica y de adoctrinamiento constitucional propiamente dicho.

\section{El Combate}

Dentro del primer grupo se sitúa el Catecismo Patriótico $(1809)^{12}$, que posee rasgos que lo acercan a la literatura panfletaria y lo convierten en una muestra representativa de esos catecismos que, según Aymes, «comme il s'agit prioritairement de repousser l'envahisseur français, [...] sont, en partie ou totalement, patriotiques» (1988: 29). En este caso, en la pregunta-respuesta con que da inicio la conexión con el modelo eclesiástico resulta clara:

P. ¿Qué quiere decir Patriota?

R. Hombre que se emplea en el bien y servicio de su Patria. [...]

P. ¿El Patriotismo es virtud moral o teologal?

R. El Patriotismo es una virtud moral, que nace de la caridad, y se funda en la justicia (1).

Bajo el mismo tono de combate y desde la perspectiva de la exaltación patriótica se va a hacer eco de la teoría del contrato social:

P. ¿Cómo se funda la justicia?

R. Porque entre los hombres y su Patria hay un contrato de justicia que mutuamente los liga.

P. ¿En qué consiste ese contrato?

R. En que la Patria nos da el ser, nos mantiene, y nos defiende, ya con leyes, y ya con armas; y nosotros por nuestra parte debemos contribuir a la conservación, honor y gloria de la Patria (1).

Más adelante, la traición a la Patria se convierte en el mayor de los pecados y su defensa se antepone a la propia vida, por lo que el lego sorprendido pregunta:

P. ¿Muy estrecha es, Padre, esa doctrina?

R. Esta es, hijo, la doctrina del Evangelio, y su autor Jesucristo nos enseña que es estrecho el camino del cielo (4).

Continúa con una somera descripción de los males que se cernirán sobre los españoles en caso de que mande Napoleón: se perderá la religión cató-

${ }^{12}$ Riaño (1922: 1809, 57-58) indica que en el Diario Mercantil de Cádiz del domingo 29 de enero de 1809 (p. 116) se anuncia su venta. 
lica, casas y fincas serán tomadas por las tropas mientras «los hombres desde 19 hasta 50 años irían desposados a servir en los ejércitos de Prusia, de Alemania, de Nápoles y de Turquía [...]» (7) y las mujeres «serían concubinas y esclavas de los franceses» (7). Así las cosas, la guerra contra el francés se convierte en una cruzada, en la que no hay que escatimar en gastos para lograr la victoria, prueba de ello es la diatriba que el anónimo autor coloca a modo de colofón, en la que la captación de voluntades y materiales para la causa bélica resulta evidente:

P. ¿Qué deberá hacer en estas circunstancias un Español patriota y generoso?

R. Obedecer lo primero sin réplica ni murmuración al Gobierno Central; marchar sin excusa ni retardación al ejército, siendo persona a propósito; contribuir con dinero, ropa, alhajas, armas y demás; tener por deshonra de la familia el no hacer algo de particular por la Patria; animar y fortalecer a los unos, aconsejar a los otros; pedir a Dios continuamente el buen éxito de nuestras armas, y hacernos dignos de ser oídos por el Señor con nuestra buena vida y costumbres. De este modo confundiremos en breve nuestros enemigos, restituiremos a su trono al deseado FERNANDO, y libertando a la Europa del yugo cruel del Tirano mereceremos nombre inmortal delante de Dios y de los hombres (p. 8).

Como se advirtió anteriormente, la influencia de las circunstancias históricas queda plasmada en estas formas propagandístico-pedagógicas; en esta ocasión, las derrotas que el ejército español está sufriendo ante las huestes napoleónicas son patentes en este catecismo de 1809, marcado por el tono antifrancés y la defensa de la religión patria. Esto provoca que conceptos profanos se carguen de simbología religiosa: el patriotismo se convierte en virtud moral, la traición en pecado y la lucha contra el pérfido francés es el camino al cielo.

\section{LA EsPeCUlación TeÓRICO-PEDAGÓGICA}

Frente a este catecismo marcado por la concisión, que no presenta división en títulos o capítulos, y que empieza de manera abrupta ponderando con ello su tono combativo, en aquellos que surgen desde 1810, cuando ya es una realidad la instalación de esas Cortes constituyentes basadas en el principio de la soberanía nacional, la complejidad argumental será mayor, en tanto que pretenden difundir los principios en que se cimenta el nuevo orden. José Luis Bermejo apunta que «será bajo los auspicios del movimiento constitucional cuando el género de los catecismos alcance un alto desarrollo y profundización» (1986: 110).

En efecto, los catecismos y cartillas que se publican en esta fecha, y que he denominado de especulación teórico-pedagógica, suelen aparecer precedidos de una breve introducción o prólogo donde el autor - por lo 
general escudado en el anonimato $\mathrm{u}$ ofreciendo simplemente las siglas de su nombre, salvo en el caso de Andrés de Moya Luzuriaga- realiza una declaración programática de los motivos que le llevan a ofrecer la obra y la conveniencia de ésta a la sociedad, siendo el argumento más frecuente la imperiosa necesidad de formar a los ciudadanos en determinados principios políticos, con el objeto de afianzar el nuevo sistema que aspira a convertirse en constitucional. Así, el ciudadano y su posición en la sociedad se convierten en el eje de reflexión de estos catecismos, cuya finalidad podría sintetizar la máxima ciceroniana con la que Moya Luzuriaga da principio al suyo: «Salus populi suprema lex esto» ${ }^{13}$.

Ahora bien, si se atiende a su contenido y a la complejidad argumental que sustenta numerosas veces la reflexión teórica, se podrá vislumbrar que aunque aparentan querer llegar a un público amplio, casi siempre se dirigen a ese grupo de personas én cuyas manos estaba el gobierno de la patria.

José Manuel Vadillo en la breve presentación que hace de la «Cartilla Política», que inserta en el $\mathrm{n}^{\circ} 15$ de El Observador 25/IX/1810, señala que quizás sea ésta una de las primeras de esta línea cívico-doctrinal. Esta precocidad puede justificar las diferencias estructurales que presenta respecto a los demás catecismos y cartillas que incluyo en este grupo, pues aquí, aunque se abordan los mismos aspectos, no se encuentra división en apartados sino que los temas se presentan de corrido e interrelacionados unos con otros: de la definición de política se pasa a los diferentes tipos de leyes (constitucionales, económicas y criminales), de éstas a su relación con el derecho de gentes, etc. Consciente de ello Vadillo señala que

[...] no parecerá extraño que se procuren difundir en el pueblo español los conocimientos de la ciencia sublime que enseña a gobernar, para que así pueda éste graduar la justicia de los procederes de sus delegados al efecto de establecer el gobierno. Ocurrióme este pensamiento, y lo realicé a mi modo, ignorando que fuese intentado por otra alguna persona; y pareciéndome el método más oportuno formar una Cartilla política que contuviese los elementos más generales del estudio de esta ciencia, apunté en ella las ideas que comprehendí ser más a propósito y encontré substancialmente en los autores que hablan de la materia... (El Observador n. $15: 231$ ).

Además de las señaladas diferencias estructurales, la obra se singulariza porque, como se puede comprobar, se publica tan sólo un día después de que hayan sido abiertas las Cortes y está dirigida precisamente a aquellos que han de gobernar, lo que le hace suponer cierto grado de preparación intelectual en el destinatario. Entre sus contenidos destaca la definición del pacto social (harto frecuente en los catecismos de este período), para lo que hace uso de los principios de diversos autores; no sólo cita a Rousseau, sino que realiza una breve historia del concepto donde indica

${ }^{13}$ Marco Tulio Cicerón, De legibus, 3, 3, 8. 
que «Antes de Juan Jacobo, Hobbes y el eminente Locke reconocieron, aunque con alguna variación respecto a las partes contratantes, esta misma base de la sociedad que han querido refutar los célebres Hume y Godwin» (El Observador n. ${ }^{\circ}$ 15: 251).

La extensión y profundidad con que son abordados los temas en la cartilla también podrían atribuirse a las particularidades de El Observador, temprana publicación periódica que trataba «los asuntos políticos de forma docta y templadamente en la forma» (Gómez Imaz 1910: 220).

Del mismo modo, o de manera aún más evidente si cabe - téngase en cuenta que su autor será acusado de plagio del Contrato Social-, el influjo de las teorías de Rousseau resulta determinante en la Cartilla del ciudadano español ${ }^{14}$, que ocupa gran parte del Robespierre español en los números XI-XXI, (aunque se hayan introducido modificaciones para adecuarla a las circunstancias sociales $\left.{ }^{15}\right)$. Esta obra, según indica su autor, Pedro Pascasio Fernández Sardino, en la «Epístola Dedicatoria» que a modo de prólogo da principio a la cartilla, se divide en tres capítulos:

En el primer capítulo expongo los inmutables principios de la más sana política. Apoyado en éstos, e iluminando con la brillante antorcha de la razón y de la justicia paso a enumerar en el segundo capítulo los respetables fueros del ciudadano español, y en el tercero sus principales obligaciones (p. 163).

${ }^{14}$ Esta cartilla contó con una edición aparte del periódico en 1814, como se desprende de los datos del Catálogo de la librería de Quiroga, Madrid, de dicho año, reproducidos por Riaño (1822: 1811, 575-576); a este mismo folleto debe referirse Dionisio Pérez quien presupone que debió ser impreso en San Fernando o en Cádiz (1903: 106). La cartilla, al igual que otras obras de contenido político destinadas a la educación social del individuo, será reeditada durante el Trienio, según un anuncio de la Gaceta de Madrid, n. ${ }^{\circ} 11(11 / 1 / 1823)$ en la página 58: «Cartilla del ciudadano español, o breve exposición de sus fueros y obligaciones: obra escrita para los poco instruidos; y a fin de que hasta el más rudo la entienda usa de un lenguaje claro, de un diálogo sencillo y de un método analítico, procediendo siempre de lo conocido a lo desconocido, conforme al orden de la naturaleza: un cuaderno en $8 .^{\circ}$ a 4 rs. de vn. A la rústica» (Gil Novales 1975, T. II: 1115; y González Hermoso 1991: 135). No he encontrado ningún ejemplar de esta reedición del Trienio. La obra se puede consultar fotocopiada en la tesis de González Hermoso (1984 t. II: 163-336). Tateishi (1993) trata algunos aspectos de la vida de Pedro Pascasio Fernández Sardino y da noticias de su traducción de la cartilla al japonés (n. 9), que como en el caso anterior carece del número XIX hasta entonces ilocalizable. Recientemente he podido localizar por primera vez un ejemplar completo del Robespierre español, custodiado en la Real Biblioteca con la signatura III/1887; periódico del que sin contar los suplementos se publicaron 34 números. Es por ello que, para que este fragmento de la Cartilla, que ocupa las páginas 300-304, no continúe en el olvido estimo oportuno reproducirlo en un apéndice al final del texto.

15 Sobre este aspecto puede consultarse González Hermoso (1991: 134-138, 137) donde concluye que «Il est donc patent que le Contrat Social est la trame même de la Cartilla del Ciudadano español. Mais au lieu du rêve utopique de J. J. Rousseau, l'auteur du $R$. $E$. propose une adaptation politique et pragmatique qui tient compte de la réalité espagnole». 
Éstos, a su vez, se subdividen en diferentes apartados en los que el autor se propone llegar de lo más simple a lo abstracto. Tal proceder explica, en gran medida, la longitud que alcanzan algunas respuestas, así como la profundidad de contenidos conceptuales del conjunto. Y es que como él mismo apunta:

Escribo para los poco instruidos; y a fin de que hasta el más rudo me entienda, uso de un lenguaje claro, de un diálogo sencillo, y de un método analítico, procediendo siempre de lo conocido a lo desconocido, conforme al orden de la naturaleza (p. 163).

La definición de pacto social se desarrolla en el «artículo III, De la libertad natural del hombre, y del origen y formación de las Sociedades y de las leyes» ${ }^{16}$; en ella se remonta a las primeras asociaciones realizadas por el hombre:

P. No entiendo cómo puede ser compatible la libertad del hombre con la sujeción que todo Ciudadano debe tener a las leyes de su patria.

R. No lo extraño; porque para entenderlo se necesita saber cuál es la libertad natural del hombre y el origen y formación de las sociedades y las leyes.

P. Explicádmelo pues, que debe ser muy interesante.

R. Voy a complaceros. El hombre errante por los bosques no podría por sí solo defenderse de las injurias del tiempo, del rigor de las estaciones, de las enfermedades, del hambre, de la ferocidad de los animales, de las violencias e injusticias de los hombres, etc. Por esta razón mantúvose agregado por un convenio tácito a sus padres y hermanos, para auxiliarse recíprocamente. He aquí la sociedad de familia, la natural, la primera que se ha conocido (El Robespierre español n..$^{\circ} \mathrm{XI}$ : 168).

Hecha esta reflexión, arguye que el contrato social es lo que convierte al individuo en ciudadano, de ahí la importancia que adquiere la explicación del pacto:

R. [...] Entonces es cuando firma de un modo tácito, pero solemne, la escritura del contrato social. Entonces queda obligado a las augustas condiciones de este pacto sagrado. $\mathrm{Y}$ en fin, entonces es cuando pierde su libertad natural, y adquiere en cambio la civil, y con ella el respetable nombre de ciudadano (El Robespierre español n. ${ }^{\circ} \mathrm{XI}$ : 172).

La similitud de argumentos entre lo expuesto en el Contrato social de Rousseau y la cartilla de Fernández Sardino es innegable, pero en la obra del último están mucho más simplificados, además de adaptados a una estructura de pregunta-respuesta. Sin embargo, no es éste un rasgo exclusivo de la creación del Robespierre, ya que el ideario rousseauniano se

${ }^{16}$ En el original aparece como «capítulo» pero por su ubicación debe entenderse artículo. Corresponde a la primera entrega de la obra en El Robespierre español n. ${ }^{\circ} \mathrm{XI}$, p. 167. 
encuentra más o menos desarrollado en el mayor número de los catecismos, cartillas, discursos, etc., de este momento.

Andrés de Moya Luzuriaga en la introducción a su Catecismo de Doctrina Civil $^{17}$ justifica como sigue la composición de éste:

En una situación tan crítica nada he creído más importante que la formación de un Catecismo de Doctrina política o civil, el cual contenga las bases del derecho natural, del derecho civil o público, y del derecho de gentes; para que los ciudadanos se instruyan en los principios sobre que debe apoyarse y versar la máquina social (52).

Será, quizás, por ello que la definición de sociedad civil se realice en el primero de los siete capítulos que componen la obra, donde según Riaño de la Iglesia «las ideas reformistas del autor se expresan bien a las claras» (1922: 1810, 510):

P. ¿Cómo se forman las sociedades?

R. Conviniendo los jefes de cada familia en que es menester respetar al más débil para ponerse a cubierto de los ataques del más fuerte, y convenciéndose los contratantes en la necesidad de acordar estatutos para juzgar a los que quebranten el pacto social; para todo lo cual eligen entre sí los más expertos y les dan amplias facultades para que en su nombre sancionen las leyes y elijan los ejecutores. Este modo de formar las sociedades es legal y justo (54).

Dentro de este segundo, grupo el Catecismo político para la instrucción del pueblo español ${ }^{18}$ será el único que no aborde la definición de pacto social. Esto puede deberse, según apunta el autor en el prólogo, a que su fin será el de «dar nociones de los objetos más comunes de la ciencia política» ${ }^{19}(113)$, de ahí que se centre en la descripción de la formación y el funcionamiento de los diferentes órganos que configuraban el sistema gubernativo, pues aunque ya existen obras destinadas a esos fines «nunca están de más las obras elementales que las expliquen, las familiaricen y

${ }^{17}$ Cito desde la reproducción de Ruiz de Azúa (1989: 49-62). Del catecismo se debió realizar una tirada bastante amplia, ya que según los datos recogidos por Pedro Riaño sobre las cuentas de la Imprenta de la Casa de Misericordia para Noviembre de 1810 se lee: «Por sola la impresión del catecismo civil incluso el cartel ......640 rs.» (1922: $1810,512)$.

${ }^{18}$ En este texto señala Capitán (1978: 77) que la presencia de los catecismos surgidos en Francia durante la revolución se hace patente, al igual que en el Catecismo Político arreglado a la Monarquía Española. Éstos, en concreto, revelan la presencia de el Catechisme de la Constitution française. La Nation, La Loi, Le Roi (1791), el Catechisme del Almanach du Pere Gerard (1792) en caso del de 1810; y el Catechisme de la Constitution republicaine (1793) en el de 1812. No obstante, y coincidiendo con JeanRéné Aymes (1990), creo que más que influencia directa entre los catecismos citados se debe presuponer un sustrato común: un sistema social y político con bases similares que se plasman en sucesivos textos constitucionales.

${ }^{19}$ Sigo la reproducción del texto de Capitán (1978: 113-131). 
las introduzcan en todos los ángulos de la sociedad; y en este orden las que pueden tener más lectores merecen la preferencia; ésta se ha procurado esté al alcance de todos; y si lo está realmente, este será todo su mérito» (113). Indica Riaño con acierto que se publicó «este interesantísimo folleto antes de reunirse las Cortes y en su forma dialogada y popular se explican las más arduas cuestiones de derecho político, resultando una apología del sistema constitucional monárquico» (1922: 1810, 197).

Pese a que el anónimo autor consigue el objetivo que se propone, hasta el punto de, como señala Alfonso Capitán Díaz, convertirse su catecismo en «el primer texto escolar de educación política en la instrucción pública española» (1978: 81), recibiendo el aplauso de sus coetáneos, se le reprochará, precisamente, que no defina el pacto social, según atestigua una reseña, hasta la fecha no tomada en cuenta, que aparece en el Semanario Patriótico, n. ${ }^{\circ} 56(2 / \mathrm{V} / 1811)$, y a que a mi entender resulta reveladora de la importancia que debió poseer esta obra en relación con otras de la misma índole:

\begin{abstract}
Ahora, pues, que como en recompensa de estos tres últimos años ha manifestado la nación, desplegando su antiguo carácter, ha logrado restablecerse en la posesión de sus imprescriptibles derechos; es indispensable que se procure generalizar y perpetuar el conocimiento de ellos, para que en ningún tiempo pueda la posteridad hacernos cargo de haber desaprovechado la mejor y más oportuna ocasión de asegurar para siempre nuestra felicidad y la de nuestros descendientes. Y como nada puede conducir tanto al intento, como el que hasta los niños mamen, por decirlo así, desde su infancia las verdades fundamentales que o sirven de base o resultan inmediatamente de nuestra asociación política, no podemos menos de recomendar al efecto la presente obrita por la exactitud de sus ideas, por la claridad y precisión de su estilo, y por lo adecuada que es para la instrucción de la niñez en este importante asunto (140).

Haciendo de esta obrita todo el aprecio que justamente merece, y sin que nuestras observaciones deban atribuirse a otro fin alguno, sino al deseo de contribuir por nuestra parte a la perfección; creemos que puede conducir al intento de indicar algunas reflexiones que sobre este asunto se nos ocurren. Como toda doctrina de cualquier catecismo político tenga por fundamento el primitivo pacto social, parecería natural que el primer capítulo de todas estas obras se dedicase a poner fuera de duda la existencia, naturaleza, objeto y condiciones de aquel pacto, tácito en verdad, pero efecto necesario de nuestra constitución física; y que no debe confundirse, como suele, con el que asegura la rey o al que haga sus veces, la autoridad, mientras no traspase los límites con que se la ha confiado la nación (142-143).
\end{abstract}

De estas palabras puede extraerse la conclusión de que en esta etapa de reflexión teórico-pedagógica el influjo del ideario que dio origen a la Revolución francesa se halla en la base de la nuestra y se diluye en el grueso de producciones que albergan un propósito político. Si bien, y como parece traslucirse de la introducción del catecismo de Andrés de Moya Luzuriaga, la presencia de determinados conceptos de raigambre francesa 
no es óbice para que se intente hacer creer que en España se va a repetir la historia del país vecino:

\begin{abstract}
Finalmente, si hubiese hombre tan nimio que manifieste su disgusto, exponiendo que no quisiera que llegásemos a organización política, empleando los medios y las voces que emplearon los franceses en su desgraciada revolución, bastará decirle; cuanto más que los franceses no fueron los inventores de casi ninguno de aquellos nombres, sino que los hallaron en la historia y en los publicistas. Por cierto será bien loable, además, si nosotros llegamos a constituir solidamente empleando las máximas y las cosas con que su volubilidad los ha conducido al despotismo más vergonzoso (53).
\end{abstract}

\title{
El AdOCTRINAMIENTo CONSTITUCIONAL
}

Declarada la Constitución, estas ideas no volverán a ser desarrolladas en los catecismos, ahora primará un claro valor doctrinal y didáctico, pues lo que se persigue es la enseñanza de las virtudes de ese nuevo código que, como indica Aranguren, «era para los liberales españoles una panacea de cuyas bellezas abstractas se esperaba todo» (1974: 55).

Muestra de este hecho es el Discurso sobre la Constitución del cura liberal Juan Antonio Posse, que elogia las bondades de esta nueva Biblia, cuya difusión se llevará a cabo también desde el púlpito; al igual que los catecismos, los sermones serán un mecanismo eficaz por su tradición cristiana para fomentar la imagen sagrada del código, pese a que como advierte Dufour «no todos pusieron el mismo entusiasmo en alabar la Constitución como el cura de San Andrés [...] Pero en todas las parroquias se pronunció un sermón con motivo de la presentación y juramento de la Constitución y los testimonios sobre este acto son fundamentales para intentar vislumbrar cuál fue la recepción de la Constitución por los españoles» (2002: 42). En noviembre de 1812 Posse exclamaba:

33. ¡O amados feligreses! ¡O españoles! Ya no somos esclavos de los reyes: ya somos hombres libres: [...] Este Código hará vuestra felicidad si lo observáis puntualmente, la vergüenza de todos si le echáis en olvido (Posse 1984: 272).

Esta utópica e ingenua esperanza tiene como consecuencia que la repetición casi mimética del texto constitucional sea la nota dominante en estos catecismos; y es que apremia que sea conocido por el pueblo, ya que «Todo español está obligado a ser fiel a la Constitución» (Título I, capítulo II, art. 7). Además, y como se recoge en el Tít. I Art. 25, punto sexto: «Desde el año de 1830 deberán saber leer y escribir los que de nuevo entren en el ejercicio de los derechos de ciudadano»; este condicionante, al que hay que sumarle la citada esperanza en el cambio social, explica la importancia que desde las páginas de publicaciones como El Redactor 
General o El Duende de los Cafés va a concederse a la educación del individuo:

¿Y será ya tiempo de salir de este letargo? El augusto congreso conoce la necesidad de este asunto; la Constitución priva del goce de los derechos de ciudadano al que pasado corto número de años no sepa leer y escribir; éste es el bello cimiento para que se proteja la educación, pero no es lo que necesita. El antiguo gobierno trabajó demasiado en arruinar la educación privada y pública, o por mejor decir, abandonó la primera a la casualidad, y no conoció ni aun el nombre de la segunda; es preciso, pues, que el actual gobierno trabaje mucho para que haya en España una buena educación para los individuos y para toda la sociedad. - U. I. (Redactor General n. ${ }^{\circ}$ 511: 2033).

Vamos al grano y al espíritu del artículo 25 de la Constitución política de España, donde se previene que desde el año 1830 deberán saber leer y escribir los que de nuevo entren en el ejercicio de los derechos de ciudadano. A tan loable y ventajoso fin ya se dieron las competentes providencias para el establecimiento de las escuelas gratuitas, $[\ldots]$

La educación pública es ramo tan interesante a un Estado, que por lo común decide sobre su prosperidad o su abatimiento (Duende de los Cafés n. ${ }^{\circ} 38$ : 157).

De otro lado, la conexión de los catecismos surgidos en este período con aquellos otros - Astete, Ripalda, Reinoso, etc.- que gozaban de gran tradición popular, resulta aún más tangible que en los que se escribieron en la etapa anterior. Hecho que podría atribuirse, en parte, al carácter confesional que el texto constitucional posee y en parte, al intento de hacer llegar la doctrina política al mayor número de público posible gracias a la asimilación de la fórmula por parte de los receptores, que produce un trasvase del «sagrado texto» al «sagrado código», en el cual el «creyente» es sustituido por el «ciudadano». Como señala Alfaya (1924: 78), la misión pedagógica otorgada al catecismo en este período, surgida de la convicción de que el éxito de la propagación del ideal político ha de iniciarse desde su vulgarización en la infancia, ocasiona que el contenido y la estructura del mismo se simplifiquen para adaptarse a las características del destinatario; quizás por esto suele desaparecer la introducción programática en la que el autor daba cuenta de sus objetivos, pasando directamente a una exposición lo más esclarecedora y breve posible de los títulos de la Constitución. Téngase en cuenta, además, que la propia Constitución, en dos de los artículos del título IX, justifica le existencia de estas creaciones: Art. 366 «En todos los pueblos de la Monarquía se establecerán escuelas de primeras letras, en las que se enseñará a los niños a leer, escribir y contar, y el catecismo de la religión católica, que comprenderá también una breve exposición de las obligaciones civiles»; Art. 368. «El plan general de enseñanza será uniforme en todo el reino, debiendo explicarse la Constitución política de la Monarquía en todas las universidades y establecimientos literarios, donde se enseñen las ciencias literarias y políticas». 
Los fines que con este tipo de obras se persiguen quedan patentes en el resumen que aparece en el $\mathrm{n}^{\circ} 480$ del Redactor General $(6 / \mathrm{X} / 1812)^{20}$ del Catecismo político arreglado a la Constitución de la Monarquía Española... por D. J. C. ${ }^{21}$, donde se lee:

Catecismo político arreglado a la Constitución de la Monarquía española, por $D$. J. C.-El autor que se ha propuesto en esta obra ilustrar al pueblo e instruir a la juventud en todos los esenciales beneficios que nos resultan del sagrado código de nuestras leyes fundamentales, desempeña con perfección su objeto, explicando clara y concisamente, por preguntas y respuestas, las significaciones de Constitución, nación española, ley, gobierno y sus modificaciones, Cortes etc. etc. Es obra sumamente recomendable para el uso de escuelas de primeras letras; porque acostumbrándose los niños a grabar en su mente, entre sus primeras indelebles ideas, éstas que han de formar su felicidad y la del Estado, será imposible ya a ningún tirano astuto borrarlas de su entendimiento con sofísticas interpretaciones (p. 1901).

En este folleto la esperanza en la Carta Magna está presente desde los primeros intercambios de preguntas y respuestas:

P. ¿Tenemos nosotros Constitución?

R. Tan buena que puede hacernos felices si la observamos y contribuimos a que se observe (Ruiz de Azúa 1989: 107).

La finalidad didáctica de la obra hace que partiendo de la definición de «Constitución» que ocupa la lección primera de las dieciocho que forman el catecismo, se lleve a cabo una explicación, en apariencia sencilla,

\footnotetext{
${ }^{20}$ De este anuncio se tienen noticias gracias a los datos contenidos en Bravo (1998: 29).

${ }^{21}$ Sobre la correspondencia de las iniciales con el supuesto autor del catecismo se han barajado varias hipótesis, sin llegar a una conclusión precisa. Morales (1990: 82) señala que Hidalgo (1862-1881, T. I: 376) lo atribuye a F. Castañón; Palau y Dulcet (T. IV: 118) a F. Corradi (en lo que a la edición de 1820 de esta obra se refiere) y Barbier (1872, T. I, A-D: 533-534) a Sr. Dandrade, jurisconsulto. Ruiz de Azúa (1989: 7) dice que Moral Sandoval (1982), da como autor a José Caro, hermano del Marqués de la Romana, que fue elegido Diputado por Valencia en las Cortes de Cádiz, sin que llegase a ostentar tal cargo, ya que se le imputó «no ser natural del reino de Valencia», sino de Mallorca - precisamente el catecismo será traducido al mallorquín ese mismo año «per un ciutadá español», que acaso sea José Caro- (sobre este dato puede consultarse: Chavarri Sidera 1988: 127, 398 y 400). Por su parte, Dérozier (1978: 698) da como autor de la obra a Juan Corradi: "primer redactor del Diario de sesiones, [que] ofrece una nueva edición de su catecismo político arreglado a la constitución de la monarquía española»; también Riaño (1922: 1812, 307-309), lo atribuye a Juan Corradi, y señala además de la gaditana una edición más lujosa realizada en Palma. Con esta última hipótesis es con la que coincido, ya que en documentos del cabildo de Cádiz de 6/IX/1820, al tratar la Comisión de Escuelas sobre el Catecismo constitucional de José Joaquín de Clararrosa se señala que «no lo estima preferente a los de los señores Cepero, Corradi y otros que ya están en uso en las escuelas» (Archivo Histórico Municipal de Cádiz, Libro 8134, f. 483).
} 
del contenido de esta «colección ordenada de las leyes fundamentales o políticas de una nación» que en este caso han formado «las Cortes generales y extraordinarias, instaladas en la Isla de León el día 24 de septiembre de 1810» (p. 107). Sin embargo, la explicación del texto constitucional sólo se va a centrar en los ocho primeros títulos, tal vez como consecuencia de la precipitación con que debió escribirse, como señala Ruiz de Azúa (1989: 7), o bien, porque el catecismo es en gran medida el título IX (De la instrucción pública), y la explicación del X (De la observancia de la Constitución, y modo de proceder para hacer variaciones en ella) sería útil únicamente a leguleyos, pero no a la masa del pueblo, y menos aún a esos niños de «primeras letras» a quienes se dirige esta obra, que acabará por convertirse en texto escolar.

Con el propósito de que la Constitución sea memorizada por los destinatarios se copian en numerosas ocasiones literalmente o con leves modificaciones los artículos del código indicándolo entre paréntesis:

\title{
LECCIÓN II
}

\author{
De la Nación española.
}

P. ¿Qué es la nación española?

R. La reunión de todos los españoles de ambos hemisferios (Art. I de la Constitución).

P. ¿Qué territorio ocupa esta gran nación?

R. El territorio español comprende en la península con sus posesiones e islas adyacentes, Aragón, Asturias, Castilla la vieja, Castilla la nueva [...] (Art. 10).

Las posibilidades de memorización que ofrecía del recién promulgado texto - que sigue de manera bastante fiel-, debieron amparar el éxito de esta obra que gozará de numerosas reediciones durante el período constitucional, el Trienio y la Regencia ${ }^{22}$, siendo igualmente sintomática de su alcance la traducción al mallorquín realizada en $1812^{23}$, prueba fehaciente del intento de hacer llegar al pueblo la Constitución.

A este catecismo, dentro del campo de la prensa periódica, hay que añadir el que se inserta en los números 251 y 253 (8 y 10 de abril de 1814) de El Duende de los Cafés ${ }^{24}$, y que como en su propio título indica

${ }^{22}$ Véase Morales (1990: 88-93, entradas 11, 12, 36-45, 72).

${ }^{23}$ Morales (1990: 88, entrada 13). «Catecisme politich arreglat a la Constitució de la Monarquía española: per illustració del poble, instrucció de la juvintut y us de las escolas de primeras lletras. Compost per D. J. C. y traduit en mallorquí per un ciutadá español. Palma, Imp. de Brusi, 1812, 16, 102 pp. B. G. de Navarra (citado por Del Burgo).

${ }^{24}$ A la hora de afrontar el estudio de este catecismo siempre se ha partido del trabajo de Capitán Díaz (1978), debido a que años más tarde se extravió en la Biblioteca Nacional el volumen de 1814 de El Duende de los Cafés, conservándose allí el año de 
es una imitación del de doctrina cristiana, compuesto por el Sr. Reynoso ${ }^{25}$, de manera que podría considerarse este breve compendio de teoría constitucional ejemplo probado de que «el catecismo político es hijo directo del religioso y respeta escrupulosamente su esquema formal» (Muñoz 1987: 197). En efecto, el catecismo sigue casi al pie de la letra la primera parte de la Doctrina Cristiana, que es la que se abarca en los dos días en que se publica.

La composición debió gozar de bastante éxito a juzgar por la advertencia que se hace en el número 253 del Duende de los Cafés: «Se ha reimpreso el Duende del 8 que contiene la primera parte de este catecismo, y que se halla a la venta en los puestos de papeles públicos» (p. 1172) o a la reimpresión hecha en Málaga. Una buena síntesis de su contenido la ofrece el Redactor General en los números 100 y 102 (9/IV/1814 y 11/ IV/1814) en la sección de «Impresos»:

El Duende de los Cafés, núm. 251.-Contiene la primera parte de un breve catecismo político-español-constitucional, compuesto por el Señor Reinoso, y publicado por E. D. D. E. A. Tiene por objeto hacer ver las consonancias de las máximas cristianas con los principios establecidos en la Constitución política de la monarquía española.

El Duende de los Cafés, núm. 253.- Inserta la segunda parte del Breve catecismo político-español-constitucional, que a imitación del de la doctrina cristiana, compuesto por el Señor Reinoso, presenta al público E. D. D. E. A. Es una semejanza del mismo catecismo del Reinoso, en la que se inculcan las ventajas de la Constitución, y los bienes que ha producido a los españoles.

1813 completo, y en la Hemeroteca Municipal de Madrid este año y algunos números sueltos de 1814, sin que entre ellos se encuentren los dos mencionados. El profesor Capitán Díaz, a quien aprovecho para hacer público mi agradecimiento, me facilitó una copia que conservaba de la página en que da inicio el catecismo. No obstante, recientemente, en la Real Biblioteca tuve la oportunidad de consultar un ejemplar completo de $E l$ Duende de los Cafés, con la signatura VIII/18301-18302. Igualmente, localicé la impresión que en 1814 se hace en Málaga del catecismo, citada por Alfaya (1924: 77) y recogida por Artola (1975-76: T. II 30), en la Biblioteca del Congreso de los Diputados, Fondo Histórico B 005-40-09 (Breve Catecismo político-español-constitucional que a imitación del de la doctrina cristiana compuesto por el señor Reynoso, presenta al público E. D. D. E. A. Málaga. En la Oficina de D. Luis de Carreras, plaza de la Constitución. Año de 1814. $31 \mathrm{pp}$. In $8^{\circ}$ ). Esta reedición presenta algunas diferencias respecto a la publicación periodística original: por un lado la referencia a los artículos de la Constitución se indican a modo de notas y aparecen una vez concluido el catecismo (p. 31) con el siguiente epígrafe: «Correspondencia de los artículos de esta doctrina con los de la Constitución de la Monarquía y decretos de las Cortes». Tras el catecismo aparecido en El Duende de los Cafés en los números 251 y 253 , se incluyen los «Actos de fe humana, esperanza política y amor patriótico, que todos los españoles deben hacer al despertar por las mañanas», que ocupaban el número 257 de la publicación, y que aquí se añaden sin más al catecismo bajo el escueto epígrafe «Modo de hacer estos actos» (18-30).

${ }^{25}$ La obra a la que imita es la Doctrina Cristiana de Francisco de Reynoso, obispo de Córdoba. (Palau T. XVI, entrada 265946). 
Como se desprende del extracto del Redactor General el paralelismo estructural de las creaciones de E. D. D. E. A. y Reinoso resulta obvio, constituyendo este breve catecismo el ejemplo más claro de la flagrante unión entre postulados eclesiásticos y laicos en este tipo de creaciones, en las que la doctrina política sustituirá a la cristiana. Ofrece una división en dos partes, donde, sin que exista división interna en títulos, elabora un efectivo encomio de la constitución, y como sucedía en el de $D . J$. C., señalando los artículos que trata entre paréntesis en la primera parte -que será en la que mayor importancia adquiera la explicación de ésta-, mientras que en la segunda va a desarrollar toda una sacralización del texto constitucional, por medio de la terminología cristiana presente en el sencillo manual del que bebe. La similitud existente entre ambas cristaliza en la paráfrasis política que se hace de la Doctrina Cristiana, como atestiguan estos fragmentos:

\section{PRIMERA PARTE}

P. ¿Sois español?

R. Sí, por la gracia de Dios y por la Constitución de la monarquía.

P. ¿Por qué decís por la Constitución de la Monarquía?

R. Porque ni por los merecimientos de mi padre, ni de mi madre, ni de otra criatura alguna soy español, sino por la bondad y la misericordia de Dios, que ordenó que yo naciese en este suelo, y por lo dispuesto en la Constitución de la monarquía, que declara españoles a todos los hombres libres, nacidos y avecindados en el territorio de España, y a los hijos de éstos (Art. I, 5, 10 y 18 de la Constitución.) (Duende de los Cafés n..$^{\circ}$ 251: 1161).

\section{PRIMERA INSTRUCCIÓN}

P. ¿Sois Cristiano?

R. Sí, por la gracia de nuestro Señor Jesucristo.

P. ¿Por qué decís por la gracia de nuestro Señor Jesucristo?

R. Porque ni por el merecimiento de mi padre, ni de mi madre, ni de otra pura criatura soy cristiano, sino por la bondad y misericordia de Dios, y merecimiento de Jesu-Cristo (Doctrina Cristiana 1851: 89).

P. ¿Qué cosa es gloria en la tierra?

R. Es vivir en un estado lleno de todos los bienes, libre de todos los males, en donde los ciudadanos arreglados a las leyes, y amándose mutuamente y al Soberano, gozan de libertad, seguridad y propiedad, que son los tres bienes en que se encierran todos los que sobre la tierra podemos desear (Duende de los Cafés n. $\left.{ }^{\circ} 253: 1170\right)$.

P. ¿Qué cosa es gloria?

R. Es un estado de todos los bienes y contentos posibles libres de todo mal, y a donde los bienaventurados viendo a Dios y amándole, gozan de cuantos bienes y contentos pueden desear (Doctrina Cristiana 1851: 93).

Por otro lado, en la obra aparecida en El Duende de los Cafés, además del vínculo con el modelo religioso, puede establecerse una significativa 
conexión con los hechos históricos; puesto que tan sólo un día después de que saliese la segunda parte del catecismo se producía la abdicación de Napoleón y volvía al trono Fernando VII, por entonces «el Deseado», de ahí quizás la desmedida comparación con Dios que se realiza en el último fragmento. Igualmente, en el n. 257 (14/IV/1814), en los Actos de fe humana, esperanza política y amor patriótico, que todos los españoles deben hacer al despertar por las mañanas, su desconocido y equivocado autor dirá lo que sigue:

Espero que volverá el Rey de su cautividad: que no tardará mucho, y que entonces, o se cumplirán mis anteriores esperanzas, o que una amnistía perfecta en materia de opiniones pondrá fin al azote desolador de la discordia popular.

Espero ver cumplidas todas las ideas de prosperidad que se propusieron las Cortes en la formación de las nuevas instituciones, y restituida la nación a aquel grado de esplendor que tuvo en otros siglos, ocupando un lugar distinguido entre las demás y respetada de ellas (1187).

En suma, la total confianza en el texto constitucional origina que, desde que se promulga hasta que el 11 de mayo de 1814 Fernando VII decretase la abolición de toda la obra de las Cortes, se incremente el empleo de estas estructuras religiosas con una finalidad civil que acaso la Iglesia no debía mirar con buenos ojos.

$\mathrm{Y}$ es que, para la difusión del mismo cualquier instrumento será bien recibido, resultando sintomático al respecto el anuncio inserto en El Duende de los Cafés n. 109 (17/XI/1813):

AVISO: Nueva Colección de muestras de letra bastarda, escritas y grabadas por D. José Asensio, sirviéndole de texto los principales artículos de la Constitución española, para que al paso que los niños aprendan a formar las letras se enteren de sus obligaciones y derechos.

Se venden por cuadernos en la librería de Gómez junto al correo a 20rs. Y sueltas a dos.

Por otro lado, en La Abeja Española se da cuenta de la enseñanza de los catecismos políticos en las escuelas, cuya eficacia se pone en tela de juicio, al tiempo que se denuncia que en 1813 parece haber caído en desuso:

¿En qué consiste que el día de hoy apenas se pasa por una escuela de primeras letras en que se oiga leer a los educandos la Constitución de la Monarquía, siendo así que tiempos atrás se había hecho de moda y uso general en dichos establecimientos? Nosotros bien consideramos que del modo que se hacía el estudio de la tal Constitución, no pasaba de ser una graciosa mojiganga, pues al hombre que piensa un poco, no se le oculta que la edad de 4,6 ú 8 años no es en la que el joven se halla en estado de formar juicio exacto del 
cómo y por qué de las relaciones políticas, civiles y morales del hombre en sociedad. Pero como antes no obstaba... [...]

¿Será tal vez la causa, amigo lector, el que la Constitución haya sido considerada por muchos como un objeto de moda (v. g. los calzones a la mameluca) que pasado el primer momento de capricho nadie hace caso? (La Abeja Espa$\tilde{n} o l a, .^{\circ} 276,14 / \mathrm{VI} / 1813$ «Una preguntilla para los curiosos») ${ }^{26}$.

Moda o no - $-\mathrm{y}$ aún prescindiendo de la adecuación de estas obras a los jóvenes receptores que únicamente podían limitarse a memorizar su contenido-, el miedo a la educación política del pueblo hará que tras el regreso al poder de Fernando VII los catecismos políticos sean mandados recoger con conocimiento y aprobación de Su Majestad ${ }^{27}$. Además, en el caso del catecismo de D. J. C. y el de E. D. D. E. A., el Consejo de Castilla insiste en una circular publicada el 9 de febrero de 1816 en que se retiren por contener «doctrinas sediciosas, subversivas y destructoras del orden público» (Alfaya 1924: 77).

En el caso del primero, existe también una interesante documentación conservada en el Archivo Histórico Nacional, Inquisición, legajo 4469, n. ${ }^{\circ}$ 27, de la que da noticia Paz y Meliá (1947, entrada 560), que esclarece en gran medida los motivos que llevaron a promulgar la recogida de estas obras. Se trata del «Expediente sobre la censura un librito intitulado Catecismo político arreglado a la Constitución de la Monarquía Española. En octavo por D. J. C., Palma por Miguel Domingo, 1812», hecho por

${ }^{26}$ La denuncia que se hace en este artículo de la situación de la educación, cuya reforma avanza lentamente, será puesta de relieve en otros artículos aparecidos en $L a$ Abeja Española como el titulado «Instrucción pública» n. . $^{\text {s }} 285-287$, o el que lleva por título «Proyecto de instrucción pública con arreglo a los principios de las gentes de forma» . $^{\circ} 305$ que muestra una negativa visión del éxito de tal empresa.

${ }^{27}$ Con estas palabras se indica en el T. IX de la publicación de 1827, Biblioteca de la Religión, un listado de los libros prohibidos por el edicto de la Inquisición de 25 de julio de 1815 (192-201). Los mismos datos pueden consultarse en el «Apéndice al Índice General de los Libros Prohibidos, que comprende los edictos de la Inquisición posteriores al 25 de agosto de 1805 hasta el 29 de mayo de 1819 (último que se publicó) y los decretos de S. Santidad y de la Sagrada Congregación del índice hasta 3 de marzo de 1846» del Índice General de los libros prohibidos... (1844). Entre los catecismos y cartillas aparecidos en Cádiz están los siguientes:

Cartilla del ciudadano español, por el Robespierre. Mandado recoger por decreto de 22 julio de 1815

Catecismo civil. Mandado recoger por decreto de 22 julio de 1815 .

Catecismo Patriótico. Mandado recoger por decreto de 22 julio de 1815.

Catecismo político arreglado a la constitución: impreso en Córdoba. Mandado recoger por decreto de 22 julio de 1815. (Se trata de una de las múltiples impresiones que se hicieron del de D. J. C.)

Catecismo político-constitucional: impreso en Málaga. Mandado recoger por decreto de 22 julio de 1815. (Es la versión en folleto de los tres números del Duende de los Cafés). 
el consejo de la Inquisición tras la denuncia en el tribunal de Barcelona el 17 de septiembre de 1815 del Maestro en Sagrada Teología Fray Jaime Soler, quien comienza diciendo: «He leído el Catecismo Político, y soy del parecer que es anti-cristiano-político, y por consiguiente debe prohibirse», pues en él están «copiados los principios revolucionarios, y democráticos de la Constitución Francesa de 1791». Para probar esta afirmación pasa a citar un «caso práctico»:

Después que ha establecido que el Rey de España es Monarca y que no está sujeto a responsabilidad alguna, enseña que la potestad legislativa no reside en el solo Rey, sino en la nación con su Monarca. De aquí se sigue que por legítima consecuencia que se puede enseñar la proposición condenada por el Papa Alejandro Séptimo que decía: Populus non peccat etiamsi ubique ulla causa non recipiat legem a Principem promulgatam. Porque si es verdad lo que enseña el catecismo la potestad legislativa no es en el solo Monarca independiente, sino en la nación; la ley promulgada por el Rey de España no tendrá fuerza de ley hasta que el pueblo la reciba: de consiguiente el pueblo será libre de recibirla, o no recibirla, lo que condenó Alejandro Séptimo en 24 de septiembre de 1665 bajo pena de excomunión ipso facto reservada a su Santidad.

Por su parte los calificadores del Supremo Consejo aunque manifiestan no encontrar en el catecismo ninguna proposición que pueda considerarse en rigor anti-cristiana, encuentran otros motivos por los que debe ser prohibido:

Por cuanto el infrascrito no sabe convenir con el muy Reverendo Padre maestro Fray Jaime Soler sobre la censura que Vuestra Ilustrísima le ha confiado del librito intitulado Catecismo político arreglado a la Constitución de la Monarquía, pondremos ambos separadamente nuestro dictamen.

En primer lugar en la página 54 hablando de las prerrogativas que tiene el Rey, dice que a él le toca conceder el pase, o retener los decretos cociliares, y Bulas Pontificias con el consentimiento de las Cortes si contienen disposiciones generales etc., etc ${ }^{28}$. Hay ciertos decretos que pertenecen al dogma, y otro no. Los unos, ni el Rey, ni a las Cortes pueden retenerlos, sino que deben obedecerlos, los otros pueden retenerlos y consultarlos. Por tanto entiendo que la mencionada proposición debe modificarse.

En la página 102 habla con poca moderación de Carlos IV, aunque dice la verdad $^{29}$.

${ }^{28}$ El pasaje al que se encuentre en el capítulo $\mathrm{X}$ «Del Rey», en concreto a la decimaquinta de sus atribuciones, donde se dice: «Conceder el pase, o retener los decretos conciliares y bulas pontificias con el consentimiento de las Cortes, si contiene disposiciones generales; oyendo al Consejo de Estado, si versan sobre negocios particulares o gubernativos; y si contienen puntos contenciosos, pasando su conocimiento y decisión al supremo tribunal de justicia, para que resuelva con arreglo a las leyes» (123).

${ }^{29}$ Se refiere a la respuesta que en capítulo XVIII «De las contribuciones» se da a la pregunta «¿Pero no podrá haber malversación, dilapidación, o cualquiera otro fraude en la inversión del producto de las contribuciones o impuestos?», a la que se responde: «No; porque ya la misma Constitución establece el arreglo que debe haber en la tesore- 
Hablando ahora en general de dicho libro, digo que todo él es un compendio de la nueva constitución que el Rey ha mandado retirar, y lo mismo debe practicar con este libro.

Una vez demostrado que no es anti-cristiano, lo que no niega que resulte perjudicial para la juventud, concluye que:

En atención pues a lo expuesto, y a que por otra parte esta obra es descaradamente revolucionaria, y subversiva del gobierno civil actual, y convengo con el muy Reverendo Padre Maestro Fray Jaime Soler que debe prohibirse, aunque no convengo, ni me convencen sus razones, sino las que tengo expuestas. Así lo siento salvo meliori juditio.

Dios Guarde a Vuestra Ilustrísima muchos años. Barcelona y septiembre 21 de 1815.

Besa las manos de Vuestra Ilustrísima.

(Rubrica) Fray Juan Tapies

Ambas censuras pasan luego al promotor fiscal, el Doctor Don Miguel Lorenzo y Ceballos, que el 5 de octubre de 1815 lo remite al Consejo quienes como informa el secretario Doctor Don Ciro Valls y Geli «Dijeron conformes que se prohíba in totum ese escrito».

A juzgar por los documentos conservados la lucha contra los catecismos y cartillas políticas será constante durante el período absolutista; no obstante, el germen quedaba sembrado y durante el Trienio éstas y otras obras de contenidos y objetivos similares verán la luz para convertir la Constitución en el código sagrado de ese súbdito que sería nuevamente ciudadano.

Dentro de este panorama donde prevalece la función didáctico-doctrinal del catecismo constituye un caso aparte el publicado en La Abeja Española n. $^{\circ} 275$ (13/VI/1813). Aquí, el tono pedagógico es sustituido por una marcada ironía, que podría interpretarse como prueba de la difusión y aceptación que el molde de preguntas y respuestas posee para fines políti$\cos ^{30}$. $\mathrm{Y}$ es que no se trata simplemente de una obra de carácter localista ${ }^{31}$,

ría nacional, y los términos con que debe dar cuenta anualmente a la nación del ingreso e inversión de los cuales públicos que así se llama el producto de las contribuciones, evitando de esta manera que se repita lo que sucedió en los tiempos de Carlos IV, en que las enormes contribuciones con que estaban agobiados los infelices pueblos se invertían en satisfacer la codicia y los caprichos del favorito Godoy» (137).

${ }^{30}$ Jean-Réné Aymes refiriéndose a este catecismo dirá que «Ce catéchisme amusant! marque le point extrême dans la trivialisation de ce genre d'ecrit tombé, en quelque sorte, dans le domaine public» (1988: 28).

${ }^{31}$ Ruiz de Azúa dice que «Es un excelente ejemplo de Catecismo sobre la Constitución de 1812 de corta extensión, referido sólo a algunos aspectos fundamentales de ella y dirigido a un grupo concreto de receptores de carácter localista[...]» (1989: 8). 
ya que aunque se indica un destinatario concreto, «los jóvenes del Alentejo», el autor, camuflado bajo las iniciales $L$. V., establece una lacónica y certera denuncia en clave humorística del despotismo y la tiranía, valiéndose para ello del planteamiento conceptual de los catecismos. Así, según informa el editor de este «hallazgo»:

Entre los papeles que en la revolución de Aranjuez se extraviaron en la casa allanada de nuestro Serenísimo Almirante, se halla un original catecismo político, que está dispuesto de orden, sin duda, de su Alteza Serenísima, para instruir en sus deberes como vasallos, a los niños de su nuevo reino del Alentejo, en Portugal. Es muy conciso, por lo que lo ofrecemos a la curiosidad de nuestros lectores.

Este fragmento pone de relieve la parodia que se va a desarrollar a lo largo de sus ocho páginas, y que parte de la relación con el que será sin dudas el personaje más denostado en el período constitucional, Godoy, a quien se alude en el irónico título, como futuro soberano portugués ${ }^{32}$; de ahí que pueda «considerarse como un depósito de los principios que rigen a V. A. y que por lo mismo, se le deben de justicia, las lecciones que han de formar las almas que gobernará un día».

Desde este momento, y como señala José Luis Bermejo Cabrero (1996: 530-533), el discípulo interroga al maestro empleando la terminología acuñada por la Constitución de Cádiz (presente en los ocho títulos que estructuran el catecismo: de la sociedad, del soberano, de las leyes, de los poderes, de los juicios, de las contribuciones, de la educación política y de la tranquilidad publica), y éste le responde de manera contraria a la esperada. Así a la cuestión «¿Qué es la sociedad?», el maestro responderá: «Es una reunión de hombres gobernados por un jefe, que se llama Rey, Soberano, Monarca, y que los ha sujetado por la fuerza propia, o se le han entregado porque él los conquistó» (Abeja española $\mathrm{n}^{\circ} .^{\circ} 275$ ); o de manera aún más representativa si se quiere y atendiendo al concepto de educación política que tanta importancia había cobrado, en el «Título VII» expresa lo siguiente:

\section{TÍTULO VII \\ De la educación política}

D. ¿Qué se entiende por esta palabra?

M. La instrucción y lecciones que se deben al hombre como social.

D. ¿Y a qué se reduce?

\footnotetext{
${ }^{32}$ Se recuerda el Tratado de Fontainebleau, de octubre de 1807, que supone un pacto entre Napoleón y la corona española para expulsar a los ingleses de Portugal, territorio que posteriormente, sería repartido, correspondiendo a Godoy el Alentejo y los Algarves, región que gobernaría bajo el título de Príncipe de los Algarves. Una breve muestra de literatura panfletaria sobre este evento puede consultarse en Delgado (1979: 413-421).
} 
M. A inspirarle por todos los medios posibles una ciega sumisión a los que mandan, para que no estén de estado en persuadirse que son algo en el mundo, sino cuando obran en fe de los que gobiernan, a su arbitrio (Abeja española $n .^{\circ} 275$ )

Como evidencia este pasaje, sarcasmo e ironía son las notas básicas sobre las que se construye esta obra, donde a la mera bufonada subyace una denuncia del despotismo y el ensalzamiento de los valores fijados por la Constitución formulados de manera contraria a la esperada.

Entronca por tanto el catecismo paródico de La Abeja con una serie de procedimientos en los que la sátira adquiere carácter propagandístico, convirtiéndose en una especie de proclama o alegato en la que mediante el recurso a lo que podría denominarse imaginería popular, donde Godoy va a convertirse en una verdadera bestia negra, se lleva a cabo una drástica condena del sistema gubernamental anterior, en aras de una defensa y exaltación del presente. En este sentido este catecismo se sitúa al lado de aquellos que ven la luz al iniciarse el conflicto bélico, en los que la brevedad no será obstáculo para que se lleve a cabo una acendrada defensa de los valores patrios.

Antes de concluir, creo conveniente indicar que no serán los catecismos y cartillas los únicos moldes que pese a su origen religioso se empleen con fines políticos, ya sea para la exaltación del patriotismo o lograr el adoctrinamiento, ya para burla del estado de cosas vigentes.

Una muestra bastante curiosa del uso de fórmulas y terminología religiosa con fines patrióticos lo constituye El Padre Nuestro al Rey Fernando $7^{\circ}$ :

Dice el Francés como diestro / afectando buena ley / siempre será nuestro Rey/ Don Fernando el Padre nuestro. / Yo no sé por qué pecado / nos vino el Francés a España, / mas si lo sacan con maña / quedarás santificado. / Harás que el mundo se asombre / de tu valor sin segundo, / bastando decir al mundo / Fernando sea tu nombre. / Mira la plata, o mi Dios / que se llevan sin cesar, / y si ellos lo han de llevar / más vale que venga a nos. / El socorro nada bueno / del Francés es patarata, / y España mandará en plata / si ellos dejan el tu reino ${ }^{33}$.

${ }^{33} \mathrm{El}$ manuscrito está encuadernado en un volumen que lleva por título Guerra de la Independencia 1808-1814. Papeles patrióticos, custodiado en la BN con la ubicación R/ 60150 , donde también se conserva una versión manuscrita del Catecismo civil y breve compendio de las obligaciones del español, conocimiento práctico de su libertad y explicación de su enemigo. Instrucción muy útil para la enseñanza de los niños de ambos sexos. Madrid, 1808, citado por Manuel Morales (1990: 88, entrada 17) y reproducido por Ruiz de Azúa (1990: 15-20) y por Sabino Delgado con dos variantes: Catecismo Civil, Cartagena, 1808 (1971: 294-300) y Catecismo español (1971: 300-306). 
En la misma línea se puede situar el Credo Político que aparece en $E l$ Duende de los Cafés n. $^{\circ} 5$ (6/VIII/1813):

Creo en el Soberano Congreso Nacional, sabio y poderoso, Criador de la libertad española y de la actual Regencia, que con tanto acierto y energía nos gobierna: creo en Fernando 7 el único Rey nuestro, que fue concebido por Padre sin cariño: que nació de María Luisa, modelo de la prostitución, y protectora de deleites prohibidos: que padeció debajo del poder del pérfido Godoy: que fue infamado, oprimido y tiranizado: que descendió del trono, y al tercer día fue llevado a Francia: que subió a los Cielos su inocencia, y está sentado a la diestra de los corazones de sus súbditos; y que desde allí ha de venir a pesar de los rebeldes y traidores. Creo en el espíritu santo y unión de la generosa España, en la santa causa que defiende, la comunión de los Españoles, Ingleses y Portugueses, y el perdón de los que se arrepientan y sean leales. Espero en la resurrección del antiguo valor español, la ruina de Napoleón, el triunfo de nuestra sabia Constitución, el castigo de los malvados que atizan el fuego de la discordia, y la vida y felicidad eterna de la península =Amén ${ }^{34}$.

Este credo conoció una edición aparte de la del periódico realizada en Mallorca en la imprenta de Guasp, y reimpreso en Reus en la oficina de Rubio, sin nombre de autor ni año de impresión, que denunciada en el tribunal de la Inquisición de Barcelona por el calificador capuchino Fray Ambrosio de Barcelona, será prohibida por el decreto del 29 de mayo de 1819 por «injurioso y denigrativo y profanador de cosas sagradas», según consta en el Índice General de los libros prohibidos...(1844), y puede corroborarse en el expediente sobre un credo político, que escuetamente cita Paz y Meliá (1947, entrada 576), y que se conserva en el AHN, Inquisición, leg. 4501, n. $^{\circ} 13$, en el que se hace la siguiente calificación por parte del consejo:

\section{Muy Ilustre Señor ${ }^{35}$}

Habiendo examinado con el Padre Maestro Fray Raimundo Pruenca, Doctor en Teología, y Rector actual del colegio del Carmen, a quien nombre por coadjutor, el papel titulado: Credo político, que de orden de este tribunal, se me remitió con fecha de 13 de abril de 1818, he observado lo siguiente:

$1 .^{\circ} \quad$ Falta el nombre del autor, y del tiempo en que se imprimió.

2. ${ }^{\circ} \quad$ Lo que se dice desde la línea 5 comenzando por aquellas palabras: «Que fue concebido por Padre», hasta casi la fin de la línea 7 en que se leen estas: «Protectora de deleites prohibidos», es gravemente infamatorio, y contrario al respeto, que se le debe a las personas mayormente reales.

3. Él todo es una aplicación de una sagrada cosa a cosas profanas, y por lo mismo tiene resabidos de impiedad y sacrilegio.

\footnotetext{
${ }^{34}$ El texto lo reproduce Gómez Aparicio, quien califica al periódico de más polémico que informativo, dando el credo como prueba de su estilo «irreverente y en ocasiones blasfemo» (1967: 97).

${ }^{35}$ Francisco Cels se dirige al Doctor Don Ciro Valls y Geli, secretario del Tribunal.
} 
En consecuencia los dos hemos convenido, en que debiera el tal papel prohibirse totalmente.

Barcelona 23 Julio de 1818.

F. Francisco Cels.

Fr. Ramón Pruenca.

La tercera de las censuras resulta sintomática, a mi entender, de la actitud de la Iglesia para con este tipo de creaciones. Dicha actitud debió ser aún más drástica en casos como el de la siguiente propuesta de jaculatoria de La Abeja Española n. ${ }^{\circ} 65$ (15/XI/1812), donde partiendo de la fórmula: «Santo Dios, / Santo fuerte, / Santo inmortal. / Líbranos, Señor, de todo mal», propone que se emplee para denunciar las plagas y males políticos que amenazan la estabilidad de la recién promulgada constitución, y «al llegar a aquel notable verso: líbranos, Señor, etc. Decir, por ejemplo: Líbranos, Señor de los R...s: líbranos Señor de la I...n: Líbranos Señor de los Fr...s: líbranos, Señor de los C...s: etc.».

Los textos estudiados hacen patente la evolución y cambios de contenidos de los catecismos y cartillas políticas en el transcurso de la Guerra de la Independencia. En estos cambios influyen tanto factores cronológicos como de recepción de estos escritos. Así, la misión propagandística inicial es sustituida paulatinamente por el intento de adoctrinar a la población en un sistema gubernamental basado en el principio de soberanía nacional, que vendría a suponer el ocaso del Antiguo Régimen. Las doctrinas de Rousseau son claves en la etapa de teorización sobre el sistema que desde las Cortes se está diseñando, y luego, serán sustituidas por el propio texto constitucional, pues urge que éste sea conocido con la vana esperanza de que con sólo esto quedaban sentadas las bases de la nueva sociedad, y desterrados para siempre el despotismo y la tiranía. Para ello, y como consecuencia de la facilidad para la asimilación de contenidos auspiciada por la tradición de la fórmula, el catecismo se carga del contenido político de la tribuna, para difundir la nueva «doctrina» en plazas, cafés, tertulias, iglesias, escuelas...

Sin embargo, con la vuelta de «El Deseado», los catecismos y demás fórmulas didáctico-políticas quedaban silenciadas a la par que se suprimían las reformas educativas, el Absolutismo se erigía en salvaguarda de los valores tradicionales - en principio incluso con el beneplácito de ese pueblo que volvía de la ciudadanía al vasallaje- . Habría que esperar a 1820 para que estas fórmulas volviesen a ver la luz y con ellas surgiese nuevamente la ilusión del establecimiento de un sistema social basado en los principios de libertad, igualdad y propiedad. 


\title{
APÉNDICE
}

ROBESPIERRE ESPAÑOL, NÚM. XIX

\author{
Continúa la Cartilla del Ciudadano Español \\ $\S 15$ \\ Castigo de rigor \\ Decimoquinto fuero
}

P. ¿Pueden los jueces dar tormento a algún reo, a fin de arrancarle la confesión de un delito?

R. Sólo de imaginarlo me horrorizo. La sociedad no tiene derecho para usar de esa prueba tan bárbara, inhumana y atroz. Cualquiera juez que la mande ejecutar es digno del último suplicio.

P. ¿Y puede un ciudadano que ha recibido tortura, repetir en justicia contra el juez que la mandó?

R. Puede: pues tiene derecho, que se llama castigo de rigor.

P. ¿Y por este derecho de castigo de rigor puede repetir en justicia contra un juez una persona iniciada en un crimen, que aunque no ha sufrido el tormento, ha sido tratada con injusto rigor?

R. Puede y debe hacerlo.

P. ¿Puede ser juzgada una persona sin ser oída?

R. De ningún modo.

P. ¿Y qué debe hacer en semejante caso?

R. Usar del derecho de castigo de rigor.

\section{$\S 16$}

Proporción de penas y delitos.

Decimosexto fuero.

P. Después de haber sido juzgada legalmente una persona, y resultando delincuente ¿puede el juez o tribunal imponerla la pena que quiera?

R. No por cierto; sino aquella precisamente que es proporcionada al crimen, y que está señalada por la ley.

P. Y si un juez arbitrariamente impone a un reo un castigo contra la ley, ¿qué debe hacer éste entonces?

R. Alegar en justicia el derecho de proporción de penas y delitos. Pues es un crimen todo gravamen de castigo que la ley señala.

\section{$\S 17$}

Derecho retroactivo

Decimoséptimo fuero

P. ¿Las leyes civiles o criminales pueden obligar a los ciudadanos antes de haberse sancionado? 
R. De ningún modo; pues no pueden tener efecto retroactivo.

P. Si una persona ha cometido una acción contraria a la ley, antes de establecida ésta, ¿será criminal?

R. No por cierto.

P. Y si se le impone alguna pena por dicha acción, ¿qué deberá hacer?

R. Alegar el derecho retroactivo.

P. ¿Qué significa derecho retroactivo?

R. El derecho, que asiste a todo ciudadano, para ejecutar una acción contraria a la ley, que se ha sancionado después de dicha acción.

\section{APÉNDICE al artículo de la seguridad personal}

P. ¿Y no hay algún medio de afianzar estos fueros pertenecientes a la seguridad personal de los ciudadanos?

R. En la actualidad no le hay expresamente; pero ya le ha habido en España. Los antiguos aragoneses tenían una institución política muy admirable, llamada el Justicia que ponía a cubierto de los tiros del despotismo su libertad civil (de la cual sólo es una parte la seguridad personal, como hemos dicho. Felipe II acabó con esta preciosa institución de los aragoneses.

P. ¿Cuál era la función principal de ese gran Justicia?

R. El proteger a los ciudadanos del despotismo ministerial.

P. ¿Se necesita al presente del restablecimiento de este antiguo Justicia de los aragoneses?*

R. Tan necesario es, que sin él los augustos fueros de los españoles sólo serán un nombre vano.

* En la actualidad nuestros aliados los Portugueses tienen una institución política admirable, llamada el Juez del Pueblo. Sus funciones son aún más extensas que las del Justicia de la constitución aragonesa. Siendo ministro del Vizconde de Ponte de Lima mandó construir un soberbio palacio, que no podía concluir por falta de algunos miles de cruzados. Con este motivo influyó con el príncipe regente, para que se subiese el jabón cuatro cuartos más de libra. A los dos o tres días de esta subida habla al Príncipe el Juez del Pueblo, (que era a la sazón un herrero), diciéndole que era preciso que se restituyera el jabón a su precio antiguo; y con efecto así se verificó el otro día.

Antiguamente eran tan poderosas las facultades del Juez del Pueblo, que podía arrestar a los Ministros y a la misma persona del Rey. En la Crónica de los Reyes de Portugal se lee que Juan V estuvo arrestado dos meses por el Juez del Pueblo. No sólo existe esta autoridad en la Capital de Portugal, sino también en cada comarca. 


\section{BiBLIOGRAFÍA CITADA ${ }^{36}$}

Alvarado, Fr. Francisco. Cartas Críticas que escribió el Rmo. Padre Maestro Fr. Francisco Alvarado del Orden de Predicadores o sea El Filósofo Rancio, en las que con mayor solidez, erudición y gracia se impugnan las doctrinas y máximas perniciosas de nuestros reformadores, y se descubren sus perversos designios contra la Religión y el Estado. Obra utilísima para desengañar a los incautamente seducidos, proporcionar instrucciones a los amantes del orden, y desvanecer todos los sofismas de los pretendidos sabios, T. II. Madrid, Imprenta de Aguado, bajada de la Cruz, 1824. ARANGUREN, José Luis. Moral y sociedad. La moral social española en el siglo XIX, Madrid, Cuadernos para el diálogo, 1974.

ARtola Gallego, Miguel. Los orígenes de la España Contemporánea, Madrid, Instituto de Estudios Políticos, 1975-1976.

AlfayA, $\mathrm{M}^{\mathrm{a}}$ Concepción. Noticias para la historia económica y social de España. Teorías económico-sociales (1800 a 1820), Segovia, Mauro Lozano, 1924.

ÁlvareZ AlONSO, Clara. «Catecismos políticos de la primera etapa liberal española», en Antiguo Régimen y Liberalismo. Homenaje a Miguel Atola. 3. Política y Cultura (Eds. Pablo Fernández Albadalejo y Margarita Ortega López), Madrid, Alianza, 1997, pp. 23-35.

AYMES, Jean-Réné: «Du catéchisme religieux au catéchisme politique (Fin du XVIIIe debut du XIXe)», École et église en Espagne et en Amérique Latine : aspects idéologiques et institutionels : actes du Colloque de Tours (4-6 décembre 1987) (Introduction par Jean-Réné Aymes, Eve-Marie Fell, Jean- Louis Guereña),Tours, C. I. R. E. M. I. A., 1988, pp. 17-33.

- «Catecismos franceses de la Revolución y catecismos españoles de la Guerra de la Independencia: Esbozo de Comparación», La Revolución francesa y su influencia en la educación en España (Eds. Gabriella Ossenbach Sauter y Manuel de Puelles Benítez ), Madrid, UNED-UCM, 1990, pp. 407-436.

BARBIER, Antoine Alexandre. Dicctionnaire des ouvrages anonymes, Paris, G. P. Maisonneuve \& Larose (eds.), 1872.

Bermejo CABrero, José Luis. Máximas, principios y símbolos políticos, Madrid, Centro de Estudios Constitucionales, 1986.

- «Prensa política en los orígenes del constitucionalismo», Anuario de Historia del Derecho Español, Tomo LXVI, Madrid, 1996, pp. 615-651.

Biblioteca de la Religión o sea Colección de obras contra la incredulidad y errores de estos últimos tiempos. T. IX. Madrid, Imprenta de D. E. Aguado, 1827.

BRAVo LiÑáN, Francisco. «La propensión lectora en el Cádiz de la Ilustración: su reflejo en El Redactor General», Cuadernos de Ilustración y Romanticismo. GES. XVIII, n. ${ }^{\circ}$ 6, Universidad de Cádiz, 1998, pp. 11-40.

CAStro, Adolfo de. Cádiz en la Guerra de la Independencia. Cuadro Histórico, por el Ilmo. Sr. D: Adolfo de Castro. $2^{a}$ ed. Publícalo el Ayuntamiento. Cádiz, Librería de la Revista Médica, plaza de San Agustín, núms. 4 y 5, 1864.

CAPITÁN Díaz, Alfonso. Los catecismos políticos en España (1808-1822). Un intento de educación política del pueblo, Granada, Caja General de Ahorros y Monte de Piedad de Granada, 1978.

${ }^{36}$ No incluyo las publicaciones periódicas ni los catecismos y cartillas utilizados, ya que supondría una repetición innecesaria de lo que queda referido en el cuerpo del estudio. 
- «Los catecismos políticos en los inicios del siglo XIX español: un intento de formación política y social del pueblo», La Revolución francesa y su influencia en la educación en España, (Eds. Gabriella Ossenbach Sauter y Manuel de Puelles Benítez), Madrid, UNED-UCM, 1990, pp. 437-449.

Castells, Irene y Moliner, Antonio. Crisis del Antiguo Régimen y Revolución Liberal en España (1789-1845), Barcelona, Ariel, 2000.

CABARRús, Conde de. «Carta Segunda. Sobre los obstáculos de opinión y el medio de removerlos con la circulación de las luces, y un sistema general de educación», Cartas 1792. Madrid, Fundación Banco Exterior, 1990.

ChAVARri SiderA, Pilar. Las elecciones de Diputados a las Cortes Generales y Extraordinarias, 1810-1813, Centro de Estudios Constitucionales, Madrid, 1988.

Delgado, Sabino. Guerra de la Independencia. Proclamas, Bandos y Combatientes, Madrid, Editora Nacional, 1979.

DÉROZIER, Albert. Quintana y el nacimiento del liberalismo en España. Turner, Madrid, 1978

Doctrina Christiana que Don Francisco Reinoso, obispo que fue de Córdoba mandó imprimir. El ejemplar desde el que reproducimos el fragmento se haya inserto en una especie de compendio de manuales de teoría católica titulado: Catecismo de Ripalda, Astete, Reinoso, Fleuri de la Primera Comunión y de lo que precisamente ha de saber el cristiano para salvarse. Ejercicio cotidiano, misa, confesión y comunión, oraciones con indulgencias, salmos y cánticos sagrados para aprender los niños de memoria. Coordinado por el editor de la colección Ascética, D. Juan Manuel de la Vega, presbítero. Cádiz-1851. Imprenta de la Casa de Misericordia a Cargo de D. F. G. de Mier.

DUfour, Gérard. «Los Archivos Eclesiásticos», Fuentes Documentales para el estudio de la Guerra de la Independencia, Francisco Miranda Rubio (Coord.), [Pamplona], Ediciones Eunate, 2002.

Gil Novales, Alberto. Las sociedades patrióticas (1820-1823), Madrid, Tecnos, 1975.

- Diccionario Biográfico del Trienio Liberal, Madrid, Ediciones del Museo Universal, 1991.

Gómez APARICio, Pedro. Historia del Periodismo español: desde la Gaceta de Madrid (1661) hasta el destronamiento de Isabel II, Madrid, Editora Nacional, 1967.

Gómez IMAZ, Manuel. Los Periódicos en la Guerra de la Independencia (1808-1814), Madrid, Imprenta de la Revista de Archivos, Bibliotecas y Museos, 1910.

GonzÁlez Hermoso, Alfredo. Pedro Pascasio Fernández Sardino et la polémique suscitée par «El Robespierre Español», Université de Bensançon, 1984.

- Le Robespierre Espñol, Paris, Annales Littéraires de l'Université de Besançon, 425, 1991.

HAZARD, Paul. El pensamiento europeo en el siglo XVIII, Madrid, Alianza, 1985.

HIDALGO, Dionisio. Diccionario general de Bibliografía española, Madrid, Imprenta de las Escuelas Pías, 1862-1881.

Índice General de los libros prohibidos, compuesto del índice último de los libros prohibidos y mandados expurgar hasta fin de diciembre de 1789 por el señor Inquisidor General y señores del Supremo Consejo de la Santa General Inquisición, de los suplementos del mismo, que alcanzan hasta 25 de agosto y además de un index librorum prohibitorum justa exemplar romanum jussu SS. D. N. editum anno $M D C C C X X X V$, en el que van intercalado en sus respectivos lugares los prohibidos hasta fin de 1842. Con la licencia necesaria. Madrid, Imprenta de D. José Félix Palacios, editor, carrera de S. Francisco, n. ${ }^{\circ} 6,1844$.

MENÉNDEZ PELÁeZ, José - SAUgniEuX, Joël. «Catequesis e ilustración: aproximación a una encuesta bibliográfica», Archivum, Tomos XXXIV-XXXV, (1984-1985), Universidad de Oviedo, pp. 119-143. 
Moráles MuÑoz, Manuel. Los Catecismos en la España del siglo XIX, Málaga, Universidad de Málaga, 1990.

MuÑOZ PÉREZ, José. «Los catecismos políticos: de la Ilustración al Primer Liberalismo español, 1808-1812», Gades 1812-1987, n. ${ }^{\circ} 16$. pp, 191-217.

Nueva edición facsímil del Catecismo Político arreglado a la Constitución de la Monarquía Española, presentación de Enrique Moral Sandoval, Madrid, Artes Gráficas Municipales, 1982.

PAZ y Meliá, Antonio. Papeles de Inquisición: catálogo y extractos. (2. ed. Por Ramón Paz). Madrid, Patronato del Archivo Histórico Nacional, 1947.

PÉREZ, Dionisio. Ensayo de una bibliografía y tipografía gaditanas, Madrid, Administración e Imprenta, Mendizábal, 8 Dupdo., 1903.

PÉREZ VIDAL, Alejandro (ed). Bartolomé José Gallardo Diccionario crítico-burlesco del que se titula Diccionario razonado manual seguido del Diccionario razonado, Madrid, Visor, 1994.

Ponce De León y CARVAJAL, M. ${ }^{a}$ del Carmen (Marquesa de Astorga). «Prólogo» y traducción de: G. B. de Mably, Derechos y Deberes del Ciudadano. Obra traducida del idioma francés al castellano, Cádiz, Imprenta Tormentaria, 1812.

Posse, Juan Antonio. Memorias del cura liberal don Juan Antonio Posse con su discurso sobre la Constitución de 1812 (ed. Richard Herr), Madrid, Siglo XXI, 1984.

Puelles Benítez, Manuel. Educación e ideología en la España Contemporánea, Barcelona, Labor, 1980.

RiAÑo DE LA IGLESIA, Pedro. La Imprenta en la Isla Gaditana (1598-1897). Ensayo bibliográfico documentado (libros, folletos, hojas volantes). Obra premiada por la Biblioteca Nacional en 1922. La parte relativa a la Guerra de la Independencia puede consultarse en el Archivo Histórico Municipal de Cádiz, de manera manuscrita en las cajas 278 (1808-1811) y 279 (1812-1814); la copia mecanográfica -que es desde la que cito- en las cajas 5304 (1808-1810), 5305 (1811), 5306 (1812), 5307 (1813-1814).

RuIZ, Nydia M. «El género catequístico-político», Trienio, n. ${ }^{\circ} 26,1995$, pp. 15-65.

RUIZ DE AZÚA, Miguel Ángel. Catecismos políticos españoles, arreglados a las Constituciones del siglo XIX, Madrid, Comunidad de Madrid, 1989.

SEOANE, M. ${ }^{a}$ Cruz. Oratoria y periodismo en la España del siglo XIX, Valencia, Castalia, 1977.

TATEISHI, Hirotaka. «El Robespierre Español y las Cortes de Cádiz: Una revisión del liberalismo en España, Trienio, n. ${ }^{\circ} 21,1993$, pp. 153-168.

DEL VALLE LÓPEZ, Ángela. «La huella de dos pedagogos de la Revolución francesa -Talleyrand-Perigord y Condorcet- en los proyectos educativos de Jovellanos y Quintana», La Revolución francesa y su influencia en la educación en España, Madrid, UNED-UCM, 1990, pp. 141-171. 


\title{
RESUMEN
}

\section{Cartillas Políticas y Catecismos Constitucionales en el Cádiz de las Cor- tes: un Género Viejo para la Creación de una Nueva Sociedad, por Beatriz Sánchez Hita.}

Durante la Guerra de la Independencia la sencilla estructura de preguntas y respuesta con sentido unívoco del catecismo religioso se carga de contenido político, convirtiéndose de este modo en un instrumento eficaz para la transmisión de los postulados doctrinales que sustentaban el nuevo sistema social clasista, en el que la preocupación por la educación en éstos del individuo para convertirlo en ciudadano será la nota dominante. Sin embargo, van a poder apreciarse diferencias notables entre los opúsculos que surgen en el citado lapso temporal en virtud del momento y del lugar en el que ven la luz. Atendiendo al caso gaditano se distinguirán tres períodos que he denominado: «de combate», «de especulación teórico-pedagógica» y «de adoctrinamiento constitucional». Por otro lado, el fenómeno de adaptación del catecismo a las circunstancias políticas se va a dar en otras fórmulas de raigambre religiosa (jaculatorias, credos, etc.), en los que en ocasiones, y al igual que sucede con los primeros, el recurso a la sátira como mecanismo de denuncia también estará presente.

Palabras Clave: Guerra de la Independencia, Cádiz, catecismos políticos, prensa, folletos, Constitución de 1812.

\begin{abstract}
During the years of the Peninsular War, the simple crossed questions of the religious catechisms, is progressively loaded with a political sense, being a efficient way of transmission for the principles of the brand-new bourgeois social system, in which the concern about the education of the subject, in order to make him/her a citizen, will be the main characteristic. However, it will be possible notice fairly important differences within the pamphlets of this time, depending on the place and time of its publication. In the particular case of Cadiz, it wil be possible to divide catechisms in three periods: «fight», «theoretical-pedagogical speculation» and «constitutional indoctrination». On the other hand, the phenomenon of the adaptation of the catechism to political events will be found in others formulas with a religious tradition (fervent speeches, Creeds, etc.), in which sometimes, just like in the first instance, the resort to the satire as a mechanism of denunce will also be present.
\end{abstract}

Key Words: Peninsular War, Cádiz, political catechisms, press, pamphlets, Constitution of 1812 . 